\author{
Kristina Peternai Andrić \\ kpeterna@ffos.hr
}

\title{
Sličnosti i razlike u Wittgensteinovom i Derridaovom shvaćanju jezika kao djelovanja
}

\begin{abstract}
Peternai Andrić Kristina, Sličnosti i razlike u Wittgensteinovom i Derridaovom shvaćanju jezika kao djelovanja (Similarities and Differences in Wittgenstein and Derrida's Notion of Language as Action). „Poznańskie Studia Slawistyczne” 4. Poznań 2013. Adam Mickiewicz University Press, pp. 127-138. ISBN 978-83-232-2525-6. ISSN 2084-3011.

This research paper offers a comparison of the concepts of language as action presented by J. Derrida and L.Wittgenstein, including the concept of ,performative” by J.L. Austin. The conclusion is that they maintain a non-representational character of language. Relationship between sign and referent is arbitrary and signs can not have a direct reference to independent objects; rather they produce meaning through relationships with other signers. In social practice, through the use of „language games”, meaning can be stabilized and systematised by the habitual use of signs; however, this stabilization of meaning is always provisional. Regardless of the differences in the approaches by Wittgenstein and Derrida, in the end is turns out that their mutual similarities are more important. The concept of language derived from their theories has a significant role in the understanding of self and identity, which leads to a discursive-performative conception of the formation of identity. Also, some common arguments and theoretical apparatus by Wittgenstein and Derrida may contribute to a new way of thinking about democratic politics.
\end{abstract}

Keywords: J. Derrida, L. Wittgenstein, J.L. Austin, language, deconstruction, language games, performative

Početak je dvadesetoga stoljeća u humanističkim znanostima obilježen obratom $k$ jeziku, odnosno procesom koji pokriva uvide da je svaka relacija pojedinca prema zbilji uvijek već posredovana jezikom i da je ljudska djelatnost u velikoj mjeri uvjetovana i određena jezikom. Time istraživanja jezika dospijevaju u središte brojnih disciplina, a jezik postaje glavni medij kroz koji se razumijeva svijet i sve ono što svijet čini. Materijalni objekti 
ili društvene prakse svoja značenja stječu kroz upotrebu jezika, što znači da je viđenje pojedinca uvjetovano pojmovima kojima dani jezik raspolaže, ali i to da jezik na neki način uspostavlja granice onoga što je moguće misliti ${ }^{1}$. Riječju, jezik se promatra kao povlašteni medij u kojem se značenja stvaraju i komunikacijom dalje prenose.

Još od nove kritike i ruskog formalizma s početka prošloga stoljeća jezik postupno preuzima primat, a šezdesetih se godina 20. stoljeća počinje tragati za jezikom književnih tekstova, odnosno njihovom dubinskom strukturom ili gramatikom. Ipak, još se raniji Wittgenstein smatra jednim od prethodnika obrata $k$ jeziku pri čemu se uzimaju u obzir njegove teze o tome da filozofski problemi nastaju prvenstveno zbog nesporazuma o logici jezika te njegova zapažanja o jezičnim igrama. Sam pojam obrata $k$ je$z i k u$ u širi opticaj lansirao je istoimeni zbornik radova urednika Richarda Rortyja 1967. godine ${ }^{2}$ čime je jezik zauzeo središnje mjesto i postao glavni medij kroz koji se razumijeva svijet i sve ono što svijet čini - događaji, stvari, pojedinci, zajednice.

Prva faza analitičke filozofije svela je proučavanje jezika na bavljenje logikom, no u trenutku kada filozofija jezika prerasta u analizu i kritiku diskursa, prije svega nastojanjima britanskog filozofa Johna L. Austina, počinju se razvijati istraživanja o pragmatičnoj dimenziji značenja i o govornim činovima. Pragmatičarska nastojanja u prvi plan lansiraju koncepciju jezika kao djelovanja reaktualizirajući, zapravo, romantičarsku tradiciju mišljenja koja vodi od Johanna Herdera i Wilhelma von Humboldta. Jezik se razumijeva kao instrument djelovanja što znači da je govorenje činjenje.

Pitanje jezika kao djelovanja najkoherentnije uobličenje doživjelo je u radovima Ludwiga Wittgensteina i Johna L. Austina. Wittgenstein i Austin svoje su teze razvili neovisno jedan o drugom, pristupajući jezičnim

\footnotetext{
${ }^{1}$ Cf. pristupe: The Philosophy of Language, ur. A.P. Martinich, New York-Oxford 1996; Representation: cultural representations and signifying practices, ur. S. Hall, London-Thousand Oaks-New Delhi 1997; C. Barker, Cultural Studies. Theory and Practice, London-Thousand Oaks-New Delhi 2003; A. Stroll, Analitička filozofija u dvadesetom veku, prev. R. Jovanović, Beograd 2005.

${ }^{2}$ Zbornik The Linguistic Turn. Essays in Philosophical Method okuplja radove M. Schlinka, R. Carnapa, G. Rylea, N. Malcoma, W.V.O. Quinea, S. Cavella, R. Harea, P.F. Strawsona, J.J. Katza i mnogih drugih.
} 
pitanjima iz drukčijih filozofskih ishodišta, međutim zaokupljale su ih slične nedoumice i izricali su slične sumnje. U terminologiji koju su pritom uveli na prvi pogled nema podudarnosti, osim što pristupi oba autora obiluju, za ondašnje prilike, neobičnim pojmovima. U Wittgensteinovu diskurzu ističu se pojmovi: jezična igra, forma života, izvjesnost, obiteljska sličnost, gramatika, značenje, istina, besmislica i drugi; Austin pak uvodi: konstativ, (posrećeni i neposrećeni) performativ, ilokuciju, lokuciju, perlokuciju, uvjete prikladnosti. Sve navedene pojmove, uz veće ili manje preoblike s obzirom na njihovo prvotno pozicioniranje, teorija je postupno ugradila u svoj diskurz te su oni danas gotovo nezaobilazni u suvremenim raspravama unutar humanističkih znanosti.

Koncept jezika kao djelovanja Wittgenstein uvodi u drugoj fazi rada (Smeđa i plava knjiga, Filozofska istraživanja, O izvjesnosti) gdje jezik promatra kao vrstu djelovanja ili alata s tim što svaki jezik počiva na dogovoru. Koncepciju jezika kao djelovanja, odnosno mogućnost jezičnog utjecaja na druge i njegovu komunikacijsku nužnost Wittgenstein eksplicitno izriče: „bez jezika ne možemo na druge ljude tako i tako utjecati; ne možemo graditi ceste i strojeve, etc. A također: bez upotrebe govora i pisma ljudi se ne bi mogli sporazumijevati” ${ }^{3}$, nadalje, ,/i/zumiti neki jezik - to bi moglo značiti na temelju prirodnih zakona (ili u skladu s njima) izumiti napravu za određenu svrhu; to međutim ima i drugi smisao, analogan onome u kojem govorimo o izumu neke igre" ${ }^{\text {. }}$.

Riječju, za Wittgensteina je svrha jezika u djelovanju međutim on nadalje uviđa da jezik ima sposobnost djelovanja ili proizvodnje učinka i bez eksplicitnog iskazivanja, čak to da postizanje učinka ne ovisi isključivo o govorniku. Zapravo, uviđa Wittgenstein, za jezične učinke govor nije nužan, samo djelovanje se može vršiti i neverbalnom komunikacijom: ,/a/ko nekome dajem neku naredbu, sasvim mi je dovoljno da mu dam znak" "Nije važan način na koji je neka naredba iskazana, ono što je važno jest razumjeti naredbu i to prije nego li se po njoj počne djelovati. Preduvjet uspješne komunikacije jest ovladati jezikom na kojemu se ona obavlja. Wittgenstein kaže: ,/n/isam navikao mjeriti temperature u Fahrenheitovim

\footnotetext{
${ }^{3}$ L. Wittgenstein, Filozofijska istraživanja, prev. I. Mikecin, Zagreb 1998, str. 491.

${ }^{4}$ Ibidem, str. 492 .

${ }^{5}$ Ibidem, str. 503 .
} 
stupnjevima. Stoga mi jedan takav podatak o temperaturi ne kaže ništa"6. Sam način korištenja jezika unutar određene zajednice i osnovni modus svakog djelovanja Wittgenstein tumači pojmom jezične igre. Pojam uvodi na predavanjima održanim tijekom 1933. godine (zabilježenima u Smeđoj knjizi), govoreći o ukupno sedamdeset i tri jezične igre, odnosno opisa moguće svakodnevne situacije. U Filozofskim istraživanjima i knjizi $O$ izvjesnosti pojam često spominje u smislu svojevrsne upotrebe jezičnih izraza dajući, zapravo, opis svakodnevnih aktivnosti pojedinca i/ili grupe, uključivši postupke sumnjanja, vjerovanja, slijeđenja pravila, dokazivanja i slične. Značenje pojma jezične igre Wittgenstein izvodi iz složene mreže odnosa i obilježja, s tim što samo pojedina obilježja pripadaju određenoj igri. Ovim pojmom Wittgenstein premješta naglasak sa značenja jezika na njegovu upotrebu, a jezična je igra, zapravo, shvaćena kao način korištenja jezika unutar određene zajednice. „Riječ «jezična igra» treba ovdje istaknuti to da je govorenje jezika jedan dio neke djelatnosti, ili neke forme života" ${ }^{, 7}$. Svi procesi koji se nazivaju igrama (igre na ploči, igre kartama, borilačke igre i druge) imaju zajedničke elemente, točnije čitav niz sličnosti i srodnosti, riječ je o takozvanim obiteljskim sličnostima: ,/n/e mogu ove sličnosti bolje karakterizirati nego riječju «obiteljske sličnosti»; jer tako se prelamaju i križaju različite sličnosti koje postoje među članovima jedne obitelji: rast, crte lica, boja očiju, hod, temperament, etc., etc., I reći ću: «igre» tvore jednu obitelj»"

Jezične su igre omeđene konstitutivnim pravilima koja se odnose na sklop društvene životne forme. Značenja pojedine riječi izvode se ovisno o upotrebi u različitim jezičnim igrama, drugim riječima, značenja riječi ovisna su o kontekstu. Pravila jezičnih igara su arbitrarna i to u smislu da ne odgovaraju nekom obliku zbilje ili prirodnim zakonima: pravila, zapravo, oblikuju značenje iz čega proizlazi da se značenje mijenja svaki put kada se promijeni jedno od pravila. Wittgenstein je uvidio da u filozofiji upotrebu riječi često uspoređujemo s igrama $\mathrm{i}$, na neki način, računamo prema čvrstim pravilima, ali sama primjena riječi nije posvuda ograničena pravilima, pravilo češće preuzima ulogu putokaza. Jezik u Wittgensteinovu

\footnotetext{
${ }^{6}$ Ibidem, str. 508.

${ }^{7}$ Ibidem, str. 23.

${ }^{8}$ Ibidem, str. 67.
} 
diskurzu, neosporno, predstavlja vrstu djelovanja kojemu je u cilju izvesti stanovite učinke. Razlažući taj problem Wittgenstein uviđa da se u jezičnoj igri različitim riječima ili rečenicama mogu polučiti isti učinci, ali također i to da jednake riječi mogu imati različitu ulogu: „onaj tko uzvikuje «Ploča!», misli zapravo: «Donesi mi ploču!»”; odnosno ,/š/to je sad razlika između obavijesti, ili tvrdnje «Pet ploča» i naredbe «Pet ploča!»? - Pa uloga koju izgovaranje tih riječi igra u jezičnoj igri” ${ }^{\prime 0}$.

Prema Wittgensteinu pravilo se ne može slijediti samo jedanput, nego je slijeđenje pravila stvar navike (običaja ili institucije). „«Slijeđenje pravila je praksa» a ne privatan čin, zaključuje Wittgenstein. Temeljno poznavanje pravila nije znanje o njima, već dresiranost ukorijenjena u zajedničkom postupanju"11.

Teza o djelovanju kao svrsi jezika i uopće Wittgensteinovoj slična koncepcija jezika, razvijena je također u radu analitičkog filozofa J.L. Austina. Iako je jedno od prvih predavanja kojim je uveo koncepciju jezika kao djelovanja Austin održao tijekom zime 1946. godine u sklopu serije predavanja u Moral Science Clubu sveučilišta Cambridge, u vrijeme kada je ondje radio te na tim predavanjima obično prisustvovao i Wittgenstein, neki oblik korespodencije ili izravnog utjecaja jednog filozofa na drugog nije zabilježen ${ }^{12}$. Bez obzira što dvojica filozofa pitanju jezika pristupaju iz različitog filozofskog polazišta rabeći pritom različitu terminologiju, Wittgensteinova i Austinova koncepcija jezika vrlo su bliske. Kao što primjećuje V. Biti: ,/n/a crti Wittgensteinove koncepcije «jezičnih igara» (iako samostalno) Austin je početkom 60-ih godina razvio uporabnu teoriju značenja vraćajući se humboltovskoj koncepciji jezika kao djelovanja"13. Austin je u razlaganju teorije govornih činova ukazao na to da je primarna karakteristika jezika ono što njime činimo, a tek sekundarna lažnost ili istinitost iskaza. Austinovo razumijevanje jezika kao vrste alata ili sredstva koji služi postizanju nekog učinka uključuje razlikovanje dva tipa iskaza:

9 Ibidem, str. 19.

10 Ibidem, str. 21.

11 N. Miščević, Ludwig Wittgenstein, u: M. Galović, Suvremena filozofija II, Zagreb 1996, str. 338.

12 Austinovu koncepciju jezika izložila sam u K. Peternai, Učinci književnosti, Zagreb 2005, pa ovdje donosim samo ključna mjesta njegove teorije.

13 V. Biti, Pojmovnik suvremene književne i kulturne teorije, Zagreb 2000, str. 570. 
konstativa i performativa ${ }^{14}$. Razabravši da se (uspješna) izvedba govornog čina ne može klasificirati propisanim pretpostavkama, odnosno da određenje performativa ovisi prvenstveno o kontekstu, Austin je uveo takozvane uvjete prikladnosti tumačeći ih kao sposobnost stvaranja odgovarajućih uvjeta unutar kojih će se performativ prikladno razumjeti. Ipak, čvrsto određenje navedenih pojmova dekonstruirano je već unutar Austinova diskurza kada je sam uvidio da je govornim činovima moguće postići učinke i bez izričitog performativnog glagola, s druge strane konstativi se u smislu tvrdnje ili opisa stanja stvari pojavljuju vrlo rijetko. Ti uvidi navode Austina da konstativ proglasi tek osobitim slučajem performativa. Tako shvaćenim performativom obuhvaća se cijelo polje jezika i on postaje samostalna tvorevina neovisna o subjektu ili adresatu izricanja te u razvoju svoje koncepcije Austin razlikovanje između konstativa i performativa zamjenjuje razlikovanjem triju aspekata koji se udružuju u svakom iskazu: lokucije, ilokucije i perlokucije koje predstavljaju dijelove svakog jezičnog iskaza zastupljene različitim obimom te nužno jedan aspekt dominira nad drugima.

Teorija govornih činova ispostavlja se kao ogranak filozofije djelovanja jer govorni činovi predstavljaju onu vrstu djelovanja koja uključuje intencionalno ponašanje. Austinov diskurz, posebice pojam performativa, pravu afirmaciju doživljava u suvremenoj humanistici gdje se posebno izdvaja smještanje kategorije performativa u središte tvorbe identiteta ${ }^{15}$. U Wittgensteinovu i Austinovu teorijskom diskurzu jezik se poima kao alat, a pristup jeziku kao alatu vodi $\mathrm{k}$ ideji da jezikom činimo nešto materijalno i njime djelujemo. Međutim tek će Derridaovo preuzimanje Austinovih teza, točnije njegovo preoblikovanje koncepcije performativa i uvođenje pojmova iterabilnosti i diferancije, omogućiti da se govorni čin počne promatrati kao medij tvorbe subjekta i identiteta.

\footnotetext{
${ }^{14}$ Problem performativa razrađen je u Austinovoj knjizi How to do Thing with Words objavljenoj 1962., a sačinjenoj od njegovih dvanaest predavanja održanih na Harvardu tijekom 1955. O tome više u V. Biti, Performativ u jeziku i književnosti, „Književna revija” br. 3-4, 2002, str. 129-141 i K. Peternai, op. cit., str. 15-21.

${ }^{15}$ Postupno, riječ performativ postala je jedan od ključnih pojmova suvremene teorije. U tom je procesu važnu ulogu u današnjici odigrala teoretičarka roda i feministica Judith Butler koja se, među ostalim, oslanja na Derridaova čitanja Austinove koncepcije performativa.
} 
Analitička filozofija jezika i dekonstrukcija, dugo su se poimale kao dvije radikalno suprotstavljene struje mišljenja, čemu je vjerojatno pridonijela činjenica da jedna na drugu nisu obraćale pažnju, a ako bi jedna o drugoj uopće nešto rekle, komentari su shvaćeni u negativnom ozračju ${ }^{16}$. Ipak, kontakt se dogodio 1977. godine kada je Derrida napisao Potpis događaj kontekst, esej koji se ispostavio kao povod za jednu od najznačajnijih polemika 20. stoljeća. Derrida ondje upućuje prigovore na Austinove teze, a na te prigovore reagirao je John Searle ${ }^{17}$. Pojmom iterabilnosti kojim je potkopao Austinovo razlikovanje između ozbiljnih i neozbiljnih govornih činova, Derrida je uveo mogućnost da svaka oznaka bude ponovljena i potpuno odvojena od originalnog konteksta, pritom i u novom kontekstu zadržavši funkciju punoznačne oznake. Tijekom polemike Derrida je pokazao da ne postoji nešto takvo kao što je čist ili normalan govorni čin, iako postoje efekti koji stvaraju dojam da je takvo što moguće, a ti su efekti izvedeni iz matrice koja također stvara kontaminirane, nečiste ili nametničke govorne činove. Derridaovo preispisivanje Austinove teorije performativa podrazumijeva da svaki performativni iskaz do nekog stupnja kreira nove, vlastite uvjete i zakone te transformira kontekst u koji ulazi. Štoviše, u Derridaovu poimanju, performativni iskazi nisu tek autonomni i slobodno stvoreni, nego su proizvedeni kao odgovor na hitan, neodgodiv poziv ili zahtjev koji (kako je to postavio u recentnijim radovima) postavlja le tout autre, sasvim drugi. Taj sasvim drugi autorizira i jamstvo je za performative Derridaova iskaza pa tako njegova koncepcija performativa inzistira na odgovornosti i etičkoj obvezi. Derridaovo poimanje performativa Austinovoj koncepciji pridaje pojam iterabilnosti i tezu o mogućnosti političkog angažmana - među ostalim i kroz književnost i književnu teoriju. Navedenim pristupima jezik se više ne shvaća kao neutralan nego je postao glavni medij za razumijevanje tvorbe vrijednosti, značenja i znanja s tim što se značenje simbolički stvara kroz označiteljsku praksu. Same riječi nose mnogobrojna moguća, potencijalna značenja, uključujući i odjeke ili tragove ostalih značenja riječi iz drugih konteksta, a označitelji generiraju značenje ne u odnosu prema fiksiranim predmetima, nego u odnosu s dru-

${ }^{16}$ Cf. Redrawing the Lines. Analytic Philosophy, Deconstruction, and Literary Theory, ur. R.W. Dasenbrock, Minneapolis 1989.

${ }^{17}$ Detaljano o polemici cf. K. Peternai, op. cit., str. 34-50. 
gim označiteljima s tim da se značenje generira kroz odnose razlike. Razmišljati o izvanjskom svijetu, kaže Derrida, možemo samo u jeziku, ne možemo zaobići jezik u nastojanju da izravno vidimo svijet, a same riječi proizvode značenje kroz mrežu odnosa u jezičnoj igri s tim što svaka dana riječ sadrži odjeke i tragove drugih značenja riječi iz drugih odnosa u različitim kontekstima. Uvodeći pojam diferancije koji sadrži i razliku i odgodu i pomak, Derrida dakle tvrdi da binarni odnosi između znakova nisu stabilni, prije će biti da je značenje nestabilno i klizi prema pojedinačnoj igri označavanja. Upravo taj proces odredio je pojmom diferancije.

Neosporno je da bliska povezanost u radu filozofa i književnih teoretičara traje već tridesetak godina. Tada su s književnom teorijom u doticaj došle ne jedna, nego dvije, u nekom smislu radikalno suprotstavljene struje: dekonstrukcija, analitička filozofija i književna teorija, s tim što je veza književne teorije i dekonstrukcije privukla više pozornosti ${ }^{18}$, dok je veza između analitičke filozofije i dekonstrukcije dugo vremena ostala u drugom planu. Njihov međuodnos tim je zanimljiviji što su mogućnost dovođenja u vezu odbijale one same, kao što primjećuje Dasenbrock, govorilo se o ,dvije različite filozofske tradicije koje su imale malošto zajedničkoga i međusoban doživljaj izražavale u iznimno negativnim pojmovima (ako bi uopće obratili pažnju na onog drugog)",19. Pitanje suodnosa tih dviju filozofskih struja postalo je nezaobilazno nakon njihovog okršaja: govorimo o maloprije spomenutoj polemici između Searlea i Derridaa koja na prvi pogled izgleda kao jasna potvrda nemogućnosti komunikacije među filozofijama, budući da se ukazuje na nepremostive razlike i u metodama i u filozofskim polazištima. Ipak, u konačnici je uočeno da Austin i Derrida imaju čak više zajedničkoga negoli Austin i njegovi institucionalni nastavljači.

Također sve do pristupa Henryja Statena 1984. godine isticale su se jedino razlike u pristupima između Wittgensteina i Derridaa. Staten među prvima upozorava na sličnosti između Derridaova i Wittgensteinova filozofskog mišljenja što se ponajprije vidi u nereprezentacijskom karakteru jezika i kontekstualnoj prirodi istine. Wittgenstein tako čak više nego Der-

\footnotetext{
${ }^{18} \mathrm{O}$ tim odnosima vidi više: Redrawing the Lines..., str. 4-5.

${ }^{19}$ Ibidem, str. 6.
} 
rida ističe pragmatičan i društveni karakter jezika u kojem se značenje pojedine riječi stabilizira kroz korištenje u pragmatičnim pripovijestima ili jezičnim igrama.

Staten Wittgensteinovu filozofsku praksu kasne faze promatra kao vid dekonstrukcije čiji je velik dio blizak Derridaovoj praksi, napominjući da su njegove dekonstrukcijske težnje vidljive već kroz neobičan fragmentaran oblik filozofskih rasprava. Iako su mnogi filozofi, bez razvijene svijesti ili barem prikladnoga naziva, prakticirali dekonstrukciju, Wittgenstein se ispostavlja kao jedinstven među mnogim Derridaovim prethodnicima zbog dosljednog dekonstrukcijskog gledišta koje počinje razvijati kroz Plavu knjigu, a čija je puna afirmacija dosegnuta u Filozofskim istraživanjima koja se mogu promatrati kao dekonstrukcijsko citanje Traktata. Samu dekonstrukciju moguće je razumjeti kao praksu (ni metodu ni znanstvenu kritiku) za koju Derrida nije dao potpunu ili konačnu definiciju, nego tek upozorio na njezine učinke u smislu proizvodnje pravila, postupaka ili tehnika. Njezina osnovna ideja jest prikaz značenja kao kontingentnog i mogućeg čime se smjenjuje klasična metafizička koncepcija. Dekonstrukcijska zadaća je misliti ujedno i pravilo i događaj, ideju i singularnost. S obzirom da je svaki slučaj različit, kao i svaka odluka, uvijek je nužan jedinstven pristup i interpretacija koja ne može biti garantirana niti jednim pravilom. Wittgenstein svoju (dekonstrukcijsku) praksu možda ponajbolje opisuje rekavši da ,/k/ad filozofi upotrebljavaju neku riječ - «znanje», «bitak», «predmet», «ja», «iskaz», «ime»-i nastoje zahvatiti bit stvari, uvijek se mora pitati: Da li se ta riječ u jeziku u kojem ima svoj zavičaj ikada doista tako upotrebljava? - $M i$ svodimo riječi s njihove metafizičke natrag na njihovu svakodnevnu primjenu" ${ }^{\text {"20. }}$.

I Wittgenstein i Derrida vlastitu filozofiju generiraju kroz gorljiv $i$ neprekinut obračun $\mathrm{s}$ tradicionalnom filozofijom, a čiju temeljnu ideju - pojam forme - dekonstruiraju, upozorava Staten. Dekonstrukciju omogućuje upravo nemogućnost transparentnih značenja i unaprijed zadanih oblika. Prisjetimo li se da za Wittgensteina riječi imaju značenje jedino u kontekstu jezičnih igara i formi života strukturiranih pomoću pravila te da se i značenje i pravila javljaju tek kao vremensko-prostorni fenomeni, a ne unaprijed zadani oblici, jasno je da ,/p/ravila za upotrebu riječi ne

\footnotetext{
${ }^{20}$ L. Wittgenstein, op. cit., str. 116.
} 
mogu dakle u Wittgensteinovom tekstu biti konstruirana kao oblik koji čini značenje prezentnim tako što ga unaprijed određuje" ${ }^{\text {21 }}$. Isto tako, značenje nije jednostavno prisutno, što znači da ,značenje više nije određeno pomoću «jest», pomoću esencije entiteta. Niti je značenje sebi prisutan oblik niti čini oblik entiteta prisutnim,"22. Upravo u toj ideji o uvijek različitom i kontekstualiziranom značenju određenom prostorno-vremenskim parametrima, Staten uočava približavanje, ako ne i stapanje, Wittgensteinove i Derridaove filozofske prakse. Napominje međutim da oni tu ideju prezentiraju na različite načine; njihovi su stilovi, svaki ponaosob, vrlo „originalni i moćni (...) srodni, iako vrlo različiti”,23. U dekonstrukcijskim praksama i Wittgenstein i Derrida pridaju pozornost pitanju interpretacije - svako je djelovanje, zapravo, interpretacija ili tumačenje - upozoravajući time na njezine paradoksne implikacije.

Sličnosti se nadalje nalaze u njihovim koncepcijama igre: Wittgenstein razumijeva igru kao aktivnost povezanu s formom života, dok je u Derridaovu diskurzu povezana s konceptima diferancije, diseminacije i sličnim, dakle igra je nužan dio dekonstrukcijske prakse. I Derrida i Wittgenstein zalažu se protiv ideje privatnog jezika: u Wittgensteinovu poimanju jezik ili kôd moraju se moći naučiti i prakticirati, a za Derridaa se svaki znak, kroz upotrebu, mora moći ponavljati, odnosno svaki znak podliježe iterabilnosti, s tim što iterabilnost preinačuje i sprječava da u pojedinom kontekstu značenje bude određeno jednom zauvijek ${ }^{24}$. Sami znakovi nemaju značenjsku jezgru i određeni su - neodredivim - kontekstom. „Derrida, poput Wittgensteina, vjeruje da su znakovi «bitno određeni kontekstom», da nemaju nepovredivu jezgru samoidentičnog značenja koja može biti shvaćena kao identična onda kada je promotrimo u različitom kontekstu" 25 .

Statenova nastojanja oko približavanja Wittgensteinove i Derridaove filozofije nastavili su Jules David Law i Steven Winspur, a Stanley Cavell i Richard Rorty također su nerijetko nastojali ukazati na sličnosti dekonstrukcije i analitičke filozofije.

\footnotetext{
${ }^{21}$ Ibidem, str. 14.

${ }^{22}$ Ibidem, str. 15.

${ }^{23}$ Ibidem, str. 26.

${ }^{24}$ J. Derrida, Limited Inc, Evanston 2000, str. 200.

${ }^{25}$ H. Staten, Wittgenstein and Derrida, London 1984, str. 122.
} 
Filozofija Wittgensteina i Derridaa bliska je na mnogim razinama počevši od osporavanja teza metafizičke filozofije, odbacivanja samoprisutnosti značenja, strateške uloge (jezične) igre i drugog, čime se otvara mogućnost za shvaćanje Wittgensteinova diskurza kroz Derridaove pojmove, ponajprije pojma dekonstrukcije, kao što to čini Staten. Međutim novije rasprave o suodnosu njihovih praksi više se usmjeravaju na različitosti i razilaženja u Wittgensteina i Derridaa ${ }^{26}$. Ti pristupi dopuštaju postojanje elemenata dekonstrukcije u Wittgensteina, ali ne i izjednačavanje njegove filozofske prakse s onom Derridaovom. Pritom se većina slaže da je sam odnos prema tekstovima iz povijesti filozofije u ta dva autora različit: dok Wittgenstein prema svojim prethodnicima pokazuje tek sporadičan interes, Derridau cijela povijest filozofije funkcionira kao tradicija podložna dekonstrukcijskoj praksi. Konkretno, prema Wheeleru, Derrida provodi dekonstrukciju ukazujući na središnji kontrast, radi na pojedinačnom tekstu i rijetko kada oblikuje alternativnu teoriju onoj dekonstruiranoj. Wittgenstein pak dekonstrukciju obavlja tako da rekonstruira različite metafizičke teorije da bi ukazao na njihovu neprimjerenost pri rješavanju pojedinih problema. Na razliku u metodologiji između njihovih filozofskih praksi upozorava također Stone držeći da Wittgensteinov oblik iskaza izlazi iz okvira Derridaove dekonstrukcije.

Bez obzira na spomenute različitosti, u konačnici se ipak važnijim ispostavljaju sličnosti u pristupima Wittgensteina i Derridaa. Ukratko, obojica zastupaju tezu o ne-reprezentacijskom karakteru jezika, za njih jezik ima odnosni karakter koji između znaka i referenta postavlja arbitrarnu vezu pa stoga znakovi ne mogu imati izravnu referenciju prema nezavisnim objektima, nego izvode značenje kroz veze s drugim znakovima. S obzirom na navedeno, svaka tvorba (značenja, vrijednosti, identiteta, istine...) jest kontekstualne prirode. U društvenoj praksi, kroz korištenje jezičnih igara, značenje može biti stabilizirano i usustavljeno kroz upotrebu, međutim ta je stabilizacija uvijek privremena. Koncepcija jezika

${ }^{26}$ Cf. J. Orbán, Nyelvjátékok, irásjátékok - Wittgenstein és Derrida, u: Z. Bagi et al., Irodalom, nyelv, kultúra, Pécs 1998, str. 65-99; S.C. Wheeler, Deconstruction as Analytic Philosophy, Stanford 2000; M. Stone, Wittgenstein on deconstruction, u: The new Wittgenstein, ur. A. Crary, R. Read, London-New York 2001, str. 83-118; N.F. Gier, Wittgenstein and deconstruction, ,,Review of Contemporary Philosophy” br. 6, 2007. 
proizašla iz njihovih teza ima značajnu ulogu pri razumijevanju sebstva $\mathrm{i}$ identiteta, s obzirom da jezik i mišljenje oblikuju subjekt što vodi $\mathrm{k}$ diskurzivno-performativnoj koncepciji pri tvorbi identiteta (a što je najviše izraženo u radovima Judith Butler). Također pojedine zajedničke teze i teorijska aparatura Wittgensteina i Derridaa (kao što su to uvidjeli Chantal Mouffe i Ernesto Laclau predloživši koncept radikalne $i$ pluralne demokracije) mogu pridonijeti novom načinu razmišljanja o demokratskoj politici. 